\title{
Thinning Florida Peaches for Larger Fruit ${ }^{1}$
}

\author{
Yuru Chang, Ali Sarkhosh, Jeffrey Brecht, and Peter Andersen²
}

The University of Florida (UF) stone fruit breeding program began in 1952, and UF has continually evaluated new peach varieties with low chill-hour requirements that are adapted to different climatic zones in Florida. A resurgence of interest in low-chill peach production in Florida has been observed, as growers are looking for a profitable alternative fruit crop to citrus. In 2016, the Florida peach industry produced over 7 million pounds of fruit (Harders et al. 2016).

Achieving a satisfactory fruit size when producing low-chill peaches with a short fruit development period under Florida's subtropical climate is still a major limitation in marketing. In the last few years, low-chill peaches showed the potential to become an economically viable fruit crop in Florida, driven partly by the spread of citrus greening (HLB). These "low-chill" varieties of peaches do not require as much winter chilling to produce fruit as traditional peach varieties that are grown farther north. Peach trees require more work to maintain than citrus (pruning twice a year and manual thinning and harvesting), but they grow quickly into a harvestable crop.

The marketing season for US-grown peaches peaks from May 20 to September 30 (Figure 1), while the target market window for Florida peaches is from the last week of March to the last week of May. Peaches are imported from Chile to the US from October to March (Figure 1). Peaches in Florida hit the market before Georgia, South Carolina, and California and have a target market window with little competition (March to May).

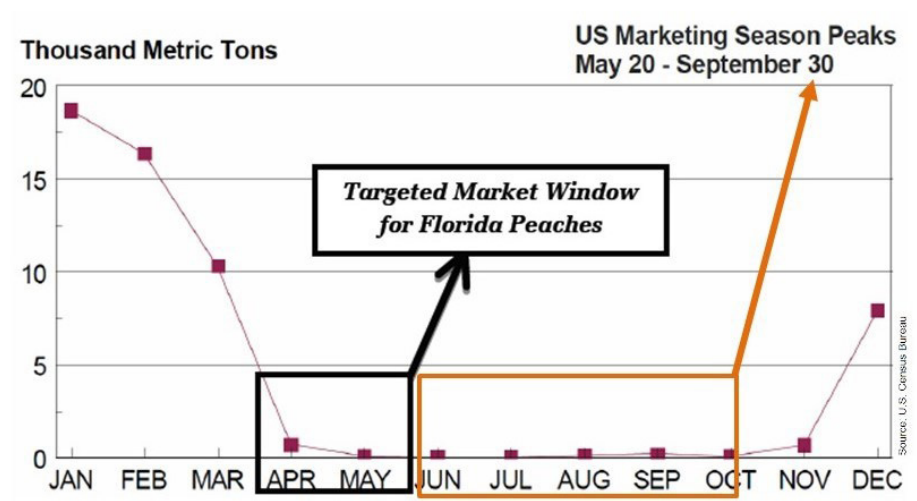

Figure 1. Annual volume of US peach imports, mainly from Chile, the main US peach marketing season, and the target market window for Florida-grown peaches.

Credits: Morgan and Olmstead (2013)

The typical fruit development period (FDP) for peaches is about 120 days, but the FDP of UF early ripening cultivars may be as short as 60-90 days. As growers can take advantage of an early market window, they also face a problem of small fruit size because of the short FDP. The cell number is the primary factor contributing to peach fruit size. Although fruit size and sweetness are not positively correlated, many retailers prefer larger size peaches and extensive red "blush" on the epidermis because of consumer preference. These retailers only accept peaches greater than 2.5 inches in diameter from the peach suppliers. Fruit thinning is critical to achieving larger sized peaches, and thus is critical to the success of peaches grown in Florida.

1. This document is HS1324, one of a series of the Horticultural Sciences Department, UF/IFAS Extension. Original publication date December 2018. Visit the EDIS website at https://edis.ifas.ufl.edu for the currently supported version of this publication.

2. Yuru Chang, graduate student; Ali Sarkhosh, assistant professor and Extension specialist; Jeffrey Brecht, professor; and Peter Andersen, professor; Horticultural Sciences Department; UF/IFAS Extension, Gainesville, FL 32611.

The Institute of Food and Agricultural Sciences (IFAS) is an Equal Opportunity Institution authorized to provide research, educational information and other services only to individuals and institutions that function with non-discrimination with respect to race, creed, color, religion, age, disability, sex, sexual orientation, marital status, national origin, political opinions or affiliations. For more information on obtaining other UF/IFAS Extension publications, contact your county's UF/IFAS Extension office. 


\section{Why thinning?}

Peach trees absorb water and nutrients from the soil and utilize sunlight to convert $\mathrm{CO}_{2}$ to carbohydrates by photosynthesis. Figure 2 shows the morphological structure of a peach fruit. All fruit on an individual tree must share these nutrients and carbohydrates; thus, excessive fruit load will cause several problems, including small size, poor flavor, excessive fruit load, delayed fruit maturation, and reduced plant vigor.

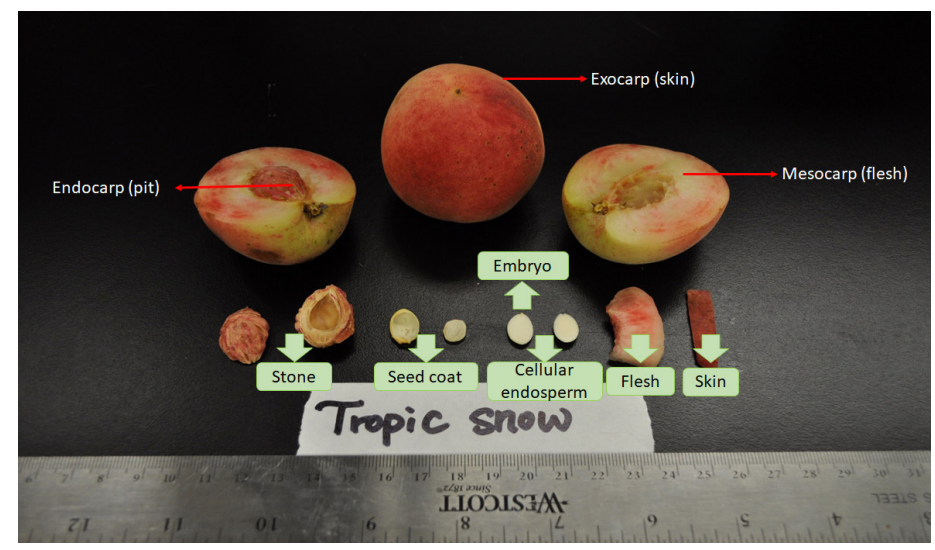

Figure 2. Peach fruit anatomy.

Credits: Y. Chang and A. Sarkhosh, UF/IFAS

Figure 3 illustrates the four stages of peach fruit development: flowering, cell division, pit hardening, and cell expansion.

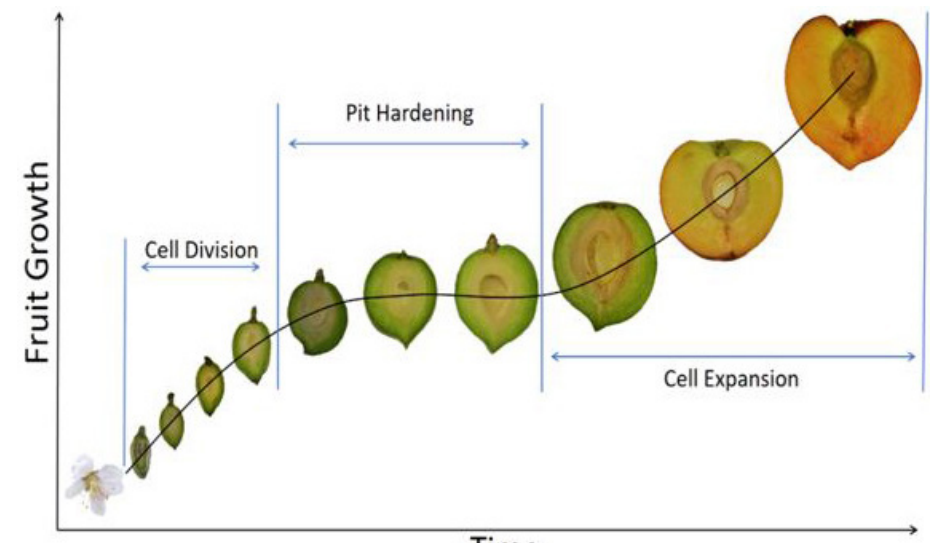

Time

Figure 3. Fruit growth stages in 'UFSun'.

Credits: D. Huff and A. Sarkhosh, UF/IFAS

After the cell division period, the pit starts hardening. Fruit thinning needs to be done during cell division before pit hardening, which occurs approximately 30 days after flowering. At this time, the stone is soft and white (Figure 4 ), and the fruit is less than one inch in diameter.

Pit hardening occurs after the cell division period. At this time the pit cells lignify, the nucellus in the seed is replaced with cellular endosperm, and the embryo replaces cellular endosperm. During the cell expansion period, the flesh cells fill with water and sugar. The pit is completely lignified, seed embryo growth is completed, and the seed coat darkens (Figure 5). The proper fruit size for fruit thinning is illustrated in Figure 6.

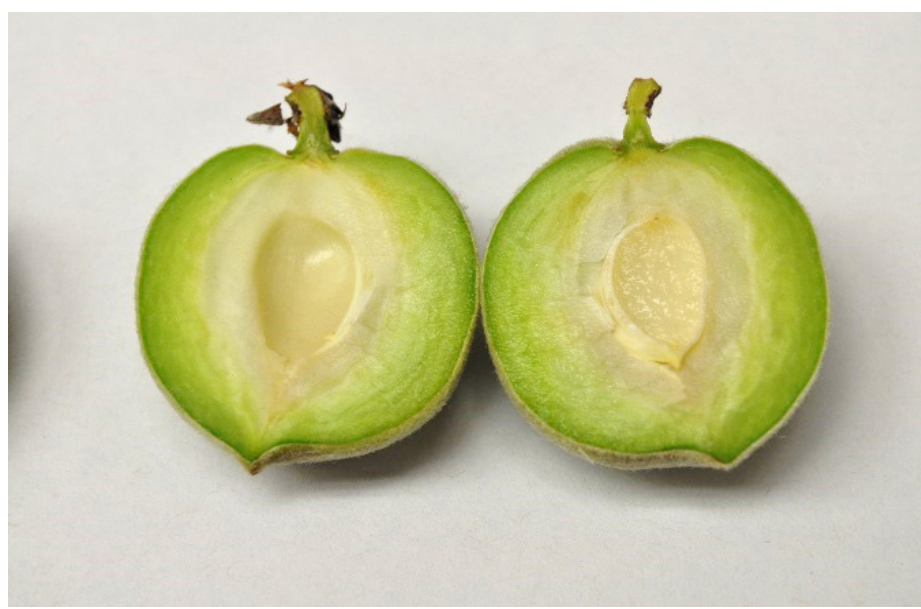

Figure 4. Straight-cut of peach before pit hardening stage. Credits: D. Huff and A. Sarkhosh, UF/IFAS

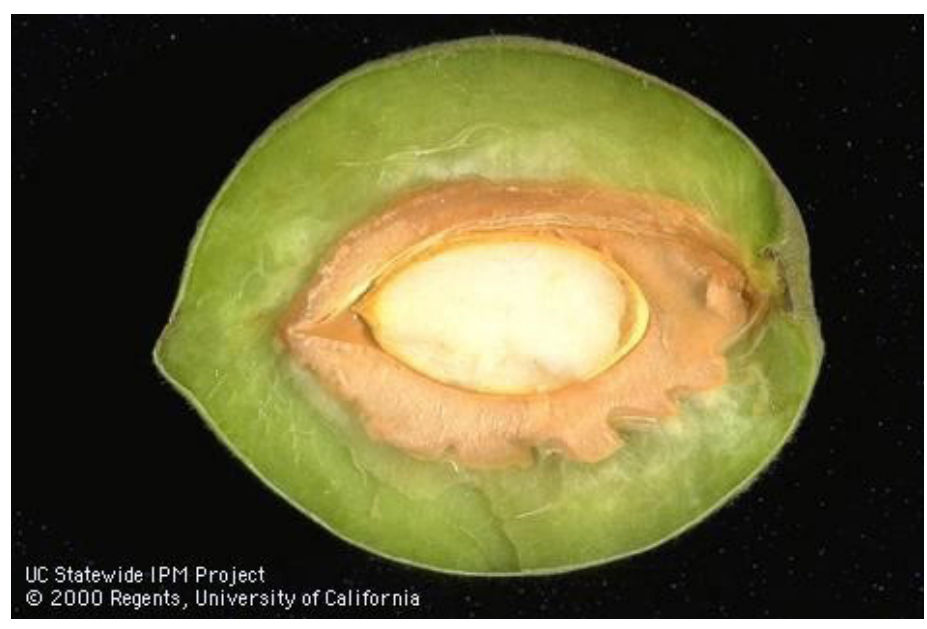

Figure 5. Straight-cut of peach after pit hardening stage. Credits: J. K. Clark

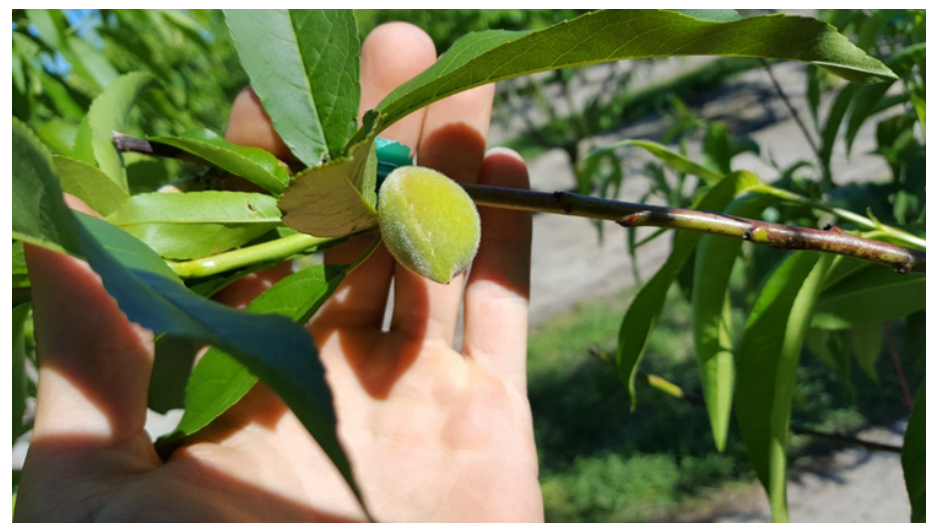

Figure 6. A good fruit size stage to do thinning. Credits: A. Sarkhosh, UF/IFAS 


\section{Thinning Advantages}

Proper fruit thinning will lead to a larger fruit size, increased nutrient accumulation, increased Brix (i.e., sugar content), and can also reduce limb breakage. Figure 7 illustrates limb breakage and an abundance of small size and low-quality fruit on an un-thinned tree. By contrast, over-thinning can lead to depressed yield and increase the incidence of the physiological disorder split pit.

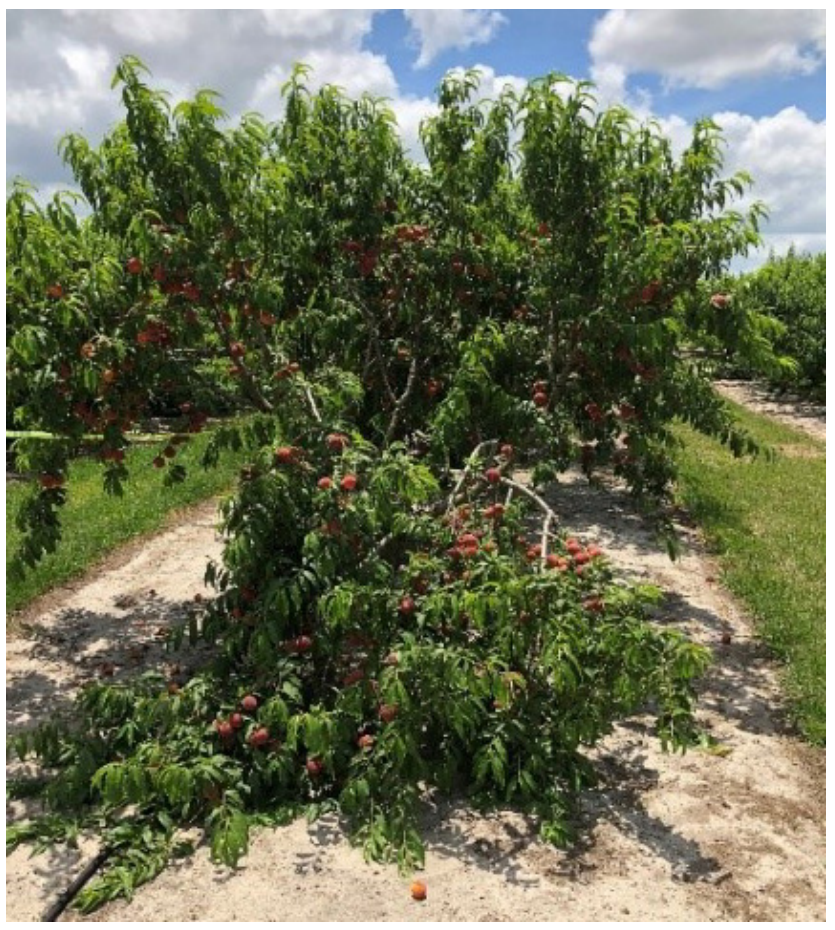

Figure 7. No thinning can result in overloaded and broken limbs. Credits: A. Sarkhosh, UF/IFAS

\section{Time of Thinning}

The time of the year to do thinning depends on the variety and local climate. Generally speaking, the earlier the thinning, the better the fruit size and quality and the more benefits can be achieved. Thinning needs to be done before pit hardening (that is, when the fruit can still easily be cut through the fruit pit). Pit hardening usually occurs when the fruit reaches the equivalent of between a nickel or a quarter coin in diameter. After that time, thinning offers few advantages.

\section{Flower Thinning}

When peach trees are in bloom, flower thinning can be done selectively and is an alternative to fruit thinning. Because the flowering period in Florida is longer than in other states like California and Georgia, growers in Florida often do not need to do as much flower thinning as in those states. Many out-of-state growers thin peach trees when the trees are blooming. Thinning flowers rather than fruit allows the tree to conserve more nutrients and carbohydrates so that they can support the remaining fruit better. However, in Florida, it is risky to thin flowers too early, because freeze events in late winter can destroy a high percentage of flowers or small fruit. Many Florida growers delay fruit thinning until a crop load is known to occur with a high degree of certainty. Low-chill peaches in Florida have a longer bloom period, which means flowers, leaves, and small fruit are present at the same time. An extended harvest period is not preferred by growers because of high labor costs. Flower thinning is an option best used in south Florida where there is less late frost risk. Damage to the earlier fruit and leaves may occur if a mechanical blossom thinner is used, resulting in variation among the fruit left on a tree. However, although mechanical flower thinning can be used to reduce fruit number, it will not eliminate hand thinning of fruit.

\section{What is the best strategy to balance yield and quality?}

Ideally, for low-chill peaches there should be on average 6 to 8 inches between two fruit. Fruit thinning can be performed manually from 15 days after flower fall until the pit hardening stage. The fruit selected to remain on the tree should be determined based on the following aspects.

\section{Unhealthy Fruit}

Fifteen days after flowers fall, healthy fruit should be almost as big as a lima bean. At this time, we can begin removing the unhealthy fruit that are malformed, unfertilized, damaged by insects or pathogens, or that have a double stigma. Remember to break up fruit clusters and fruit twins that may develop. These fruit will never reach marketable quality.

\section{Leaf-to-Fruit Ratio}

Thinning fruit is recommended until the leaf-to-fruit ratio is about 20 30:1. Fruit size, tree vigor, and fertilization level may impact this ratio.

\section{The Position of Fruit in the Canopy}

Because sunlight promotes red coloration, more fruit should be left in the outside of the tree canopy as opposed to inside the canopy. Interior fruit is more likely to be shaded and have poorer coloration. Peach trees are often pruned to an open center to allow the fruit in the center of the canopy to intercept sufficient sunlight to promote the development of red color. 


\section{Type of Shoot}

Peach shoots may be long (30 inches), medium (20 inches), or short (spur) in length. Long branches can support 2 to 4 fruit, medium length branches 1 to 3 fruit, and short spurs only 1 fruit. Generally, a mature peach tree can produce as much as 2,000-3,000 fruit, but these numbers need to be reduced to about $200-400$ fruit per tree to produce fruit with a diameter over 2.5 inches.

\section{How can peaches be thinned?}

\section{Hand Thinning}

Flowers or fruit may be thinned by hand. It is labor intensive and time consuming and hence very expensive. However, hand thinning is the best method because it is more accurate, and, if done properly, it will not hurt the leaves. Figure 8 shows the proper fruit size and proper spacing to use when hand thinning. When the trees are very tall and fruit are hard to reach, growers can use a procedure known as pole-thinning, knocking fruit off the trees with poles. This method is faster but less accurate than hand thinning. To reduce damage to branches, connect a piece of cloth or a short rubber hose to the end of the pole to expand the reach.
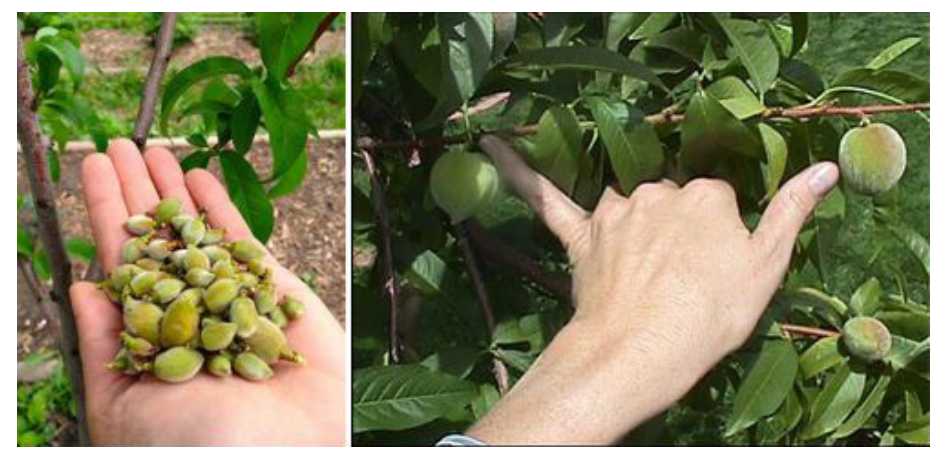

Figure 8. Hand thinning: proper fruit size and proper spacing. Credits: J. Crook, MyGardenGeek.com

\section{Mechanical Thinning}

Several machines are marketed for mechanical thinning; however, none remove the fruit or flowers evenly. Therefore, after mechanical thinning, hand thinning is still required to achieve the best results. There are a series of thinning machines called Darwin string thinners developed by a company in Germany (Johnson et al. 2010). The Darwin thinner (Figure 9) has a 10-inch rotating spindle with 2-inch long strings spaced every inch along the spindle. Many factors like spindle rotation speed, tractor speed, and string type can be changed to get the best thinning performance (Johnson et al. 2010). The string thinner is especially efficient on flower thinning of high density row systems with uniform (central leader), symmetrical canopies. When used for fruitlet thinning, there are leaves on the trees and leaves are damaged by the strings. Leaf damage results in decreasing leaf to fruit ratio and hence reduced available photosynthesis. For blossom thinning, there are almost no leaves on the tree, so leaf damage is minimal. However, in Florida, because of the tropical climate and extended bloom period, flowers and leaves occur on trees simultaneously. To avoid leaf damage, the Darwin thinner is seldom recommended in Florida.

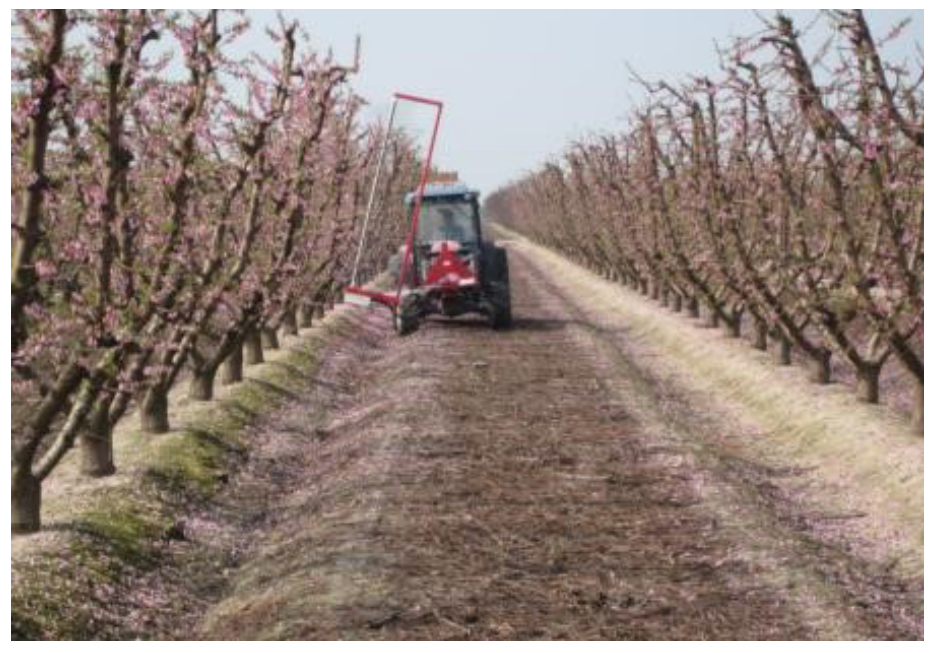

Figure 9. Mechanically thinning central leader peach blossoms using a Darwin PT250.

Credits: Fruit Report (UC-Davis)

Other fruit thinning machines include trunk shakers (Figure 10) and drum shakers (Figure 11). They are mostly used for harvesting and seldom used for thinning. The trunk shaker has a large pincer that shakes the trunk directly, and the drum shaker has vibrating rods that are inserted into the canopy.

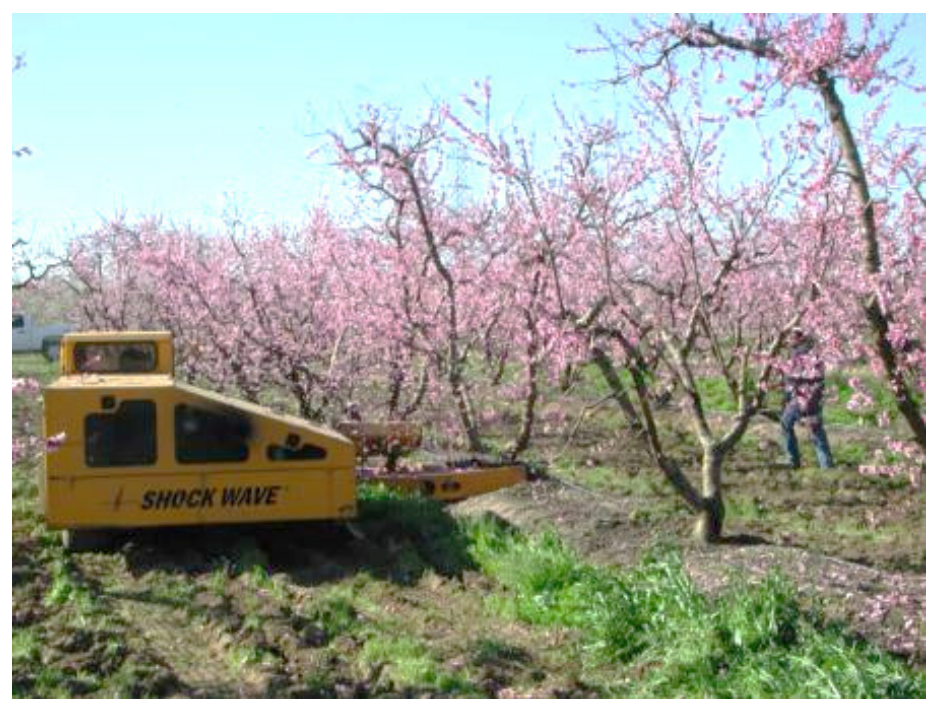

Figure 10. Trunk shaker thinning blossoms.

Credits: Fruit Report (UC-Davis) 


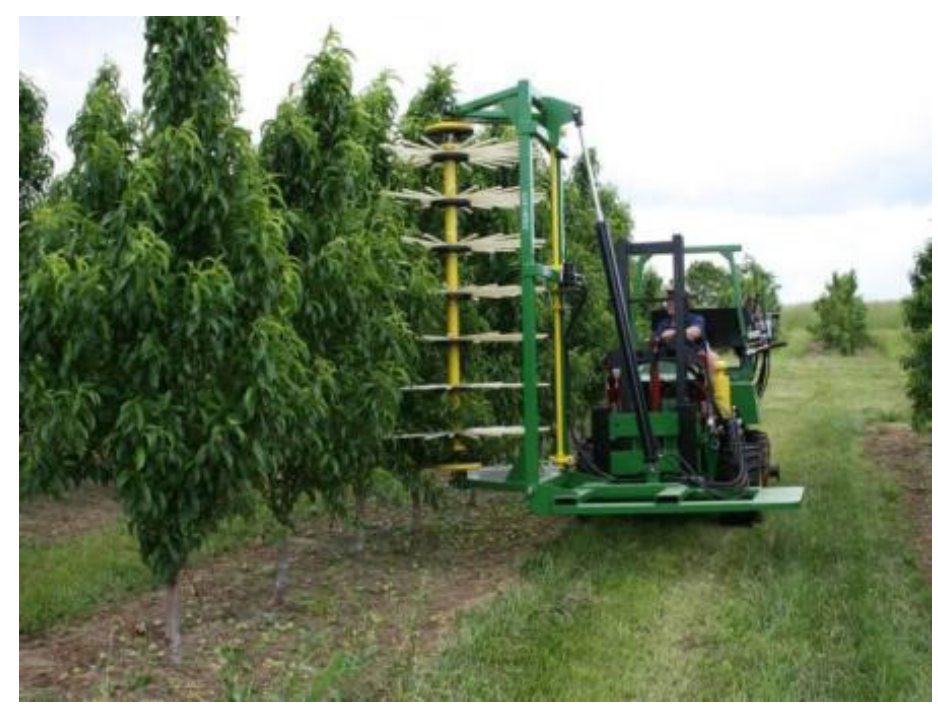

Figure 11. Drum shaker.

Credits: Fruit Report (UC-Davis)

\section{Chemical Thinning}

Many studies have tested chemicals to reduce labor input for flower and fruit thinning; however, at this time there are no chemicals for peach thinning available commercially. During experimentation, researchers have reported some disadvantages such as inconsistency or excessive phytotoxicity. A study from the University of California found Armothin (N-TER) was very promising, but it is no longer registered for thinning (https://ucanr.edu/sites/fruitreport/ Thinning/Chemical_Thinning/). More research is required before chemicals can be recommended for thinning.

\section{Results from a Fruit-Thinning Field Trial}

In 2018, a fruit-thinning experiment was conducted with 20 'UFSun' scions grafted onto 'Flordaguard' rootstock trees. Half of the trees were thinned to leave 6 to 8 inches between fruit and half were not thinned. In the first week of May 2018, five fruit from each quadrant (NE, SE, NW, and SW) were sampled, equivalent to twenty fruit from each tree (200 fruit samples per treatment). Figures 12 and 13 compare color, size, and weight between peach fruit from thinned and unthinned trees. The results showed that thinning increased the fruit weight by $45 \%$ and improved fruit diameter by $14 \%$ (Figure 14a). Figure 14b shows that the average diameter of un-thinned fruit was not of marketable size. These data demonstrate that thinning is especially critical to enhance fruit size of peaches with a short FDP that ripen in April and early May.

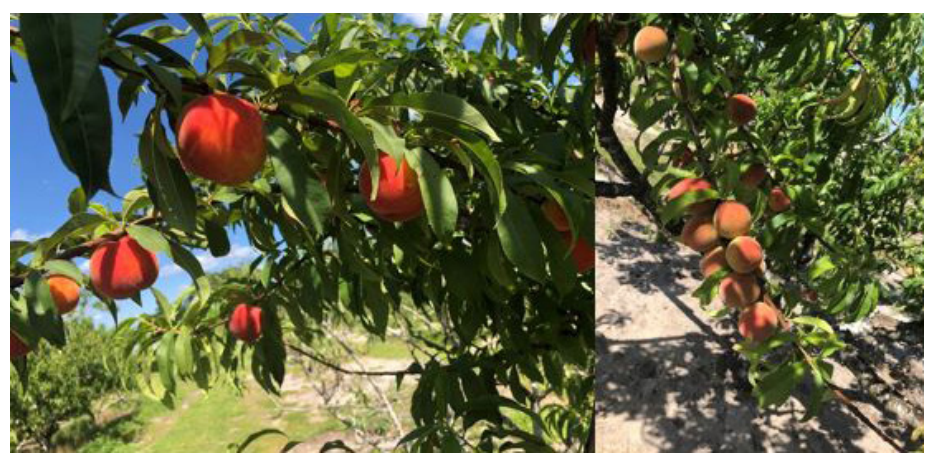

Figure 12. Fruit color comparison in thinned (left), unthinned (right). Credits: A. Sarkhosh, UF/IFAS

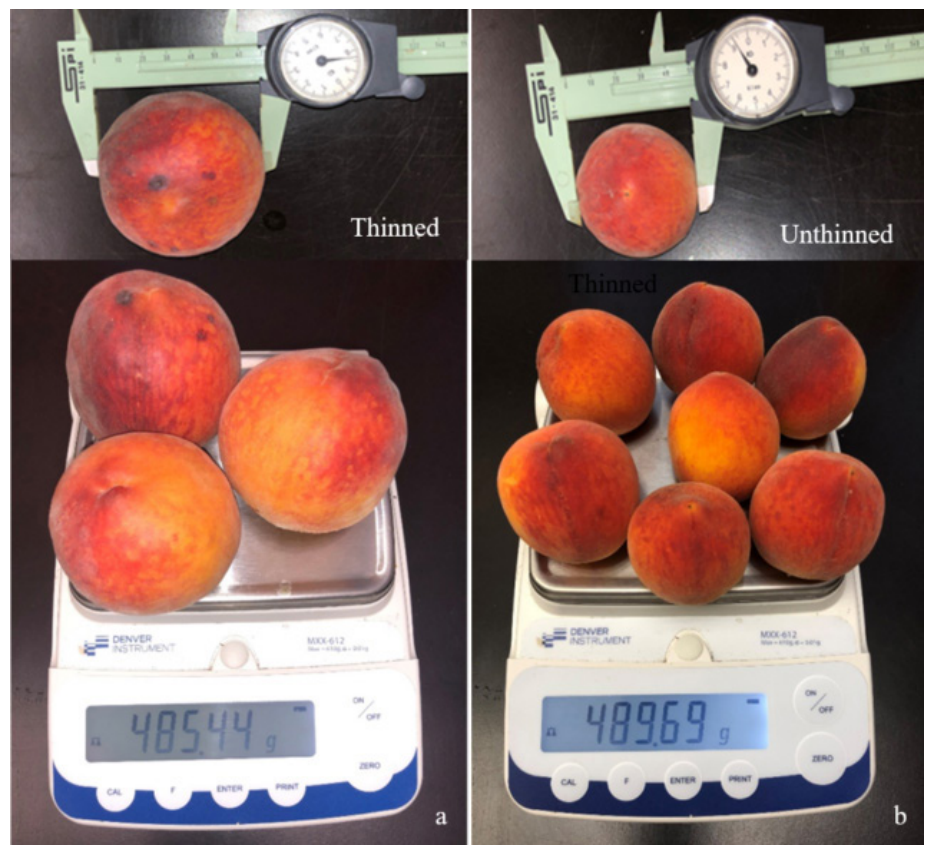

Figure 13. Impact of thinning on fruit size and weight; a) fruit thinned about 6 to 8 inches apart on the tree branches; b) fruit from an unthinned tree.

Credits: A. Sarkhosh, UF/IFAS

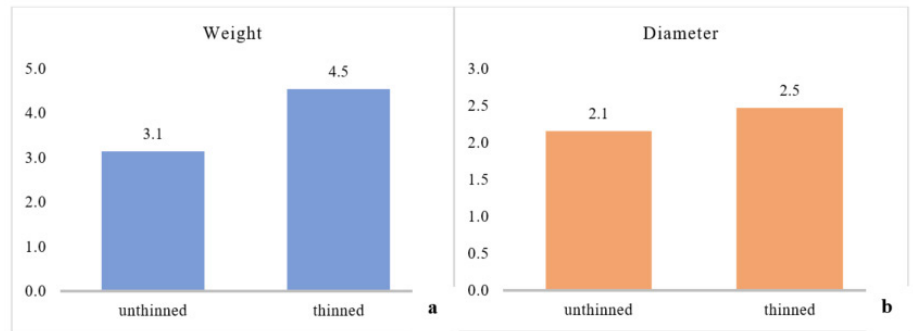

Figure 14. The results of 2018 fruit thinning experiment. a) effect on fruit weight (ounces); b) effect on fruit size/diameter (inches). 


\section{References}

Harders, K., J. Rumble, T. Bradley, L. House, S. Anderson. 2016. "Consumer Peach Purchasing Survey." http://www. piecenter.com/wp-content/uploads/2015/09/Peach-

Report_FINAL.pdf

Johnson, R. S., B. Phene, D. Slaughter, T. DeJong, K. R. Day, R. Duncan, M. Norton, and J. Hasey. 2010. "Mechanical blossom thinning using a Darwin String Thinner.” https:// ucanr.edu/sites/fruitreport/files/101631.pdf

Morgan, K., and M. Olmstead. 2013. "A Diversification Strategy for Perennial Horticulture in Florida." HortTechnology. 23: 4 . 